\title{
Interpersonal meaning in students' explanation texts
}

\author{
Dini Hadiani ${ }^{1, *}$ \\ ${ }^{1}$ Bandung Manufacturing Politechnic \\ ${ }^{1}$ dinibhs@polman-bandung.ac.id \\ * corresponding author
}

ARTICLE INFO

Article history

Received : April 20, 2019

Revised : May 9, 2019

Accepted : May 29, 2019

\section{Keywords}

Interpersonal meaning

Mood types

Modality

Explanation texts

\begin{abstract}
PT)
This study is aimed to investigate the interpersonal meaning in students' explanation texts. Six texts taken from students' writings were used as the instruments of text analysis. The theories of Systemic Functional Linguistics and explanation text were used as the framework of the text analysis. The findings show that students have employed mood types which are formed by the Subject and Finite as Mood element and predicator and complement as Residue. The arrangement of Subject and Finite in the clauses demonstrates that declarative mood is used dominantly in the texts to realize the speech function of a statement. It suggests that the students have attempted to provide the information to the readers which are relevant to the social function of the explanation text. Moreover, the little use of modality in students' texts indicates that the students present factual information. This evidence has shown the students' efforts to position themselves in the texts and to build relationships with the readers. In conclusion, students have been able to create an effective explanation text which is intended to inform how something is done.
\end{abstract}

This is an open access article under the CC-BY-SA license.

\section{Introduction}

Language is mainly used for exchanging information as well as establishing and maintaining social relationships. As it is suggested by Halliday (1994), language has a variety of meaning, and it is presented to create interaction. In Systemic Functional Linguistic perspective, language involves the systemic characteristics in which it emphasizes meaning as a choice in analyzing language, and the functional characteristics since it is designed to interpret how language is used. With regards to this, Halliday (1994) proposes three types of metafunction as the fundamental element of meaning, namely ideational, textual, and interpersonal. Ideational meaning is related to how language is used to represent experiences. Textual meaning deals with the organization of text to form coherence. While the interpersonal meaning, the focus of this study, is concerned with how language is used to maintain social relations and to indicate the role of participants in the communication (Halliday, 1994). Thus, exploring interpersonal meaning can reveal the way in which someone takes the position and builds a connection with the interlocutors.

A number of studies of interpersonal meaning have been performed in various types of fields including spoken and written texts (Feng and Liu, 2010; Amalia, Subandowo, Faliyanti nad Thresia, 2018; Sunardi, Tarjana, Poedjosoedarmo, and Santosa, 2018). A study conducted by Feng and Liu (2010) analyzed Obama's speech in terms of interpersonal meaning. The study focused on the 
realization of mood, modal auxiliary, personal pronoun and tense shift. It was found that Obama uses different devices of the language to realize the interpersonal meaning to deliver his political speech. Similarly, Amalia, Subandowo, Faliyanti, and Thresia (2018) investigated the domain Mood and Modality of Interpersonal Meaning in Susilo Bambang Yudhoyono (SBY)'s Speech. The results show that the different mood and modality can affect the value of the speech to the audience. SBY's speech is dominated by declarative mood informing the audience about the topic of his speech as well as the use of modality expressing his judgment of the thing that he says. While Sunardi, Tarjana, Poedjosoedarmo, and Santosa (2018) analyzed the realizations of interpersonal meaning in English as a Foreign Language (EFL) classrooms in Indonesian university context. The findings indicate that the EFL classrooms are dominated by declarative clause, interrogative clause, and imperative clause which are influenced by the teacher-centred teaching method used in the classrooms.

Other studies concerning the interpersonal meaning focusing on written texts have been conducted widely (see Ayoola, 2013; Yu, 2017; Yuliana and Imperiani, 2017; Arifin, 2017; Xuan and Huang, 2017). Ayoola (2013) researched the interpersonal metafunction in political advertisements in the Nigerian newspaper. His findings reveal the interpersonal meaning realized in the newspaper advertisement which is not always relevant to its lexicogrammar analysis due to the use of various mood types to establish and construct relationships with the reader. Similarly, Yu (2017) conducted research on the interpersonal meaning in terms of mood and modality in English Public Service Advertising texts. The results indicate that advertisers tend to influence readers' attitudes and behaviour by controlling the modality. In the same way, Yuliana and Imperiani (2017) studied the interpersonal meaning in newsletters offering online courses in different educational institutions, i.e. general and Islamic institution. It was found that both institutions employ typical features of modality, mood types, and the dominant use of declarative. While Arifin (2017), investigated the realization of the interpersonal meaning of non-native writers in the abstract. His study shows that the realization of the interpersonal meaning in the abstract is done through the expressions of the clause based on the mood system, the dominant use of declarative, and the dominant use of low degree modality. Furthermore, Xuan and Huang (2017) explored the understanding of interpersonal meaning-making in Chinese High School Students' ESL writing. The results show that the Chinese ESL learners' writing is familiar to overuse the particular type of modal.

Based on the elaboration of previous research on interpersonal meaning in written texts, the studies focused on texts such as a newsletter, advertisement, and academic text; an abstract and students' writing in particular. However, none has studied the interpersonal meaning specifically in explanation text. Basically, explanation text is considered important especially for engineering students as it functions to explain natural phenomena and to answer the questions of how and why. This type of text is also frequently used in the industry to explain technological processes (Gerot and Wignel, 1994; Derewianka, 2004; Martin and Rose, 2008). In addition, it was reported that engineers are demanded to give technical explanations on product design or manufacturing processes (Cullen and Pudwill, 2002). It indicates that for engineering students the ability to write a technological explanation text is needed. It is, therefore, necessary to analyze the interpersonal meaning in the explanation text. Studying the interpersonal meaning in students' explanation texts can reveal in what way students take their position and build a connection with the readers. Thus, this research attempts to investigate the interpersonal meaning specifically the mood types and modality realized in students' explanation texts.

\section{Interpersonal Meaning}

Interpersonal meaning involves two major areas: the kind of interaction occurring and the type of commodity being exchanged, and the way speakers take a position in their messages (Butt, 2002). The former deals with demanding and giving information as well as goods and services and using language to both exchange information and good and services, while the latter is concerned with how speakers or writers position themselves in an argument or discussion. 
It has been suggested that in communicative exchange, there are basically four speech roles; giving information, giving good-\&-services and demanding good-\&-services (Butt, 2002; Eggins, 2004; Thompson, 2014). The interpersonal meaning can be started by defining the primary roles of communication that correspond with the speech functions; a statement to give information, a question to demand information, an offer to give goods and services, and a command to demand good and services.

In terms of Mood types, the realization can be done through the order of mood elements. It covers declarative, interrogative, and imperative. The examples of Mood types are illustrated in the following table.

Table 1. Mood Types and Examples (Adopted from Butt, 2002)

\begin{tabular}{cc}
\hline Mood Types & Examples \\
\hline Declarative & The machine is made of steel. \\
\hline Interrogative & Does the mechanic maintain the machine? \\
\hline Imperative & Pull out the gear. \\
\hline
\end{tabular}

The realization of the communicative exchange in terms of interpersonal meaning is using Mood structure including the Mood, Finite and Residue (Eggins, 2004). The Mood element comprises two parts; the Subject, realized by a nominal group, and the Finite in the form of a verbal group encoding the primary tense or the speaker's opinion. Thus, the Finite occupies two major interpersonal roles; a TIME signal related to the speaker, or a sign of MODAL about the speaker's opinion (Butt, 2002). In terms of Residue, it is formed from Predicator by which of the non-finite verb, Complement in the form of a noun or nominal group, and Adjuncts in the form of adverbial group, and a prepositional phrase (Halliday, 1994; Gerot \& Wignell, 1994; Eggins, 2004).

During the process of interaction, the mood types are used to realize the speech functions. The connection between Subject and Finite is a sign of the interaction occurring in the discourse creating the message as a statement, a question, an offer, and a command. When writing is presenting information to the reader, writers are giving information, and they usually make statements. In terms of giving information, the Subject is put before the Finite, and this structure of the mood system is called Declarative Mood (Butt, 2002; Eggins, 2004). Thus, clauses with Subject that precedes the Finite are considered the declarative which generally realizes a statement. While speakers demanding information, usually ask questions. Sometimes they ask in polar interrogatives which expect a yes/no request. In a polar interrogative question, the Finite comes before the Subject, and this order is the signal of the Interrogative Mood as a frequent realization of a question (Butt, 2002). It means that Interrogative is characterized by the inversion position of Subject and Finite in the clauses in which Finite is positioned before the Subject. In exchanging goods and services, speakers demanding goods or services usually assign orders or commands. In this type of exchange, there is no obvious Subject or Finite, but speakers can, if they wish, make their demands more emphatic by adding a Subject or a Finite. These configurations of the Mood system are known as the Imperative Mood which normally realizes a command (Butt, 2002). While speakers giving goods and services commonly offer something. The utterance is usually expressed in modulated interrogative (Eggins, 2004).

\section{Modality}

Sometimes speakers tend to show their opinion or judgment whether something is in between positive and negative polarity. They probably use another type of Mood structure in some way. The alternative method is known as Modality (Butt, 2002; Eggins, 2004; Halliday \& Matthiessen, 2004).

Modality includes modalization and modulation. The former covers modality of probability and usuality which are related to propositions, while the latter deals with obligation and inclination which are related to proposals. As it is assumed by Eggins (2004) that speakers use modalization to declare the probability or frequency of something; while they employ modulation to show the obligation and inclination in doing something. Furhermore, Halliday and Matthiessen (2004) categorize the modalized expression into subjective orientation such as in modal verbs andexpression 'I believe, I think', etc. and objective orientation such as in the expression 'it is 
recommended that...' or in modal adverb 'frequently'. The types of modalization and modulation with examples are outlined in Table 2 below.

Table 2. Types of Modality and Examples (Adapted from Eggins, 2004)

\begin{tabular}{cccc}
\hline Modalization & Examples & Modulation & Examples \\
\hline Probability & $\begin{array}{c}\text { The assembly process will } \\
\text { finish in two hours. }\end{array}$ & Obligation & $\begin{array}{c}\text { The machine must be } \\
\text { maintained regularly. }\end{array}$ \\
\hline Usuality & $\begin{array}{c}\text { The mechanic usually } \\
\text { maintains the machine once } \\
\text { a month. }\end{array}$ & Inclination & I'll lend you some money. \\
& & \\
\hline
\end{tabular}

Table 2 shows that in different circumstances speakers or writers prefer to use a declarative with a Modal Finite expressing obligation which can be less bossy instead of ordering someone to do something in imperative way. In this situation, the speakers or writers are delivering an opinion about whether or not that something should be done (Ivanic, 1998; Ivanic and Camps, 2001). A declarative also allows the speaker or the writer to suggest that a person should do an action.

\section{Interpersonal Meaning in Explanation Text}

The explanation text is principally to inform why something happens or how something is done. Consequently, the purpose of the communicative exchange is giving information which is typically written in the declarative form (Butt, 2002; Eggins, 2004; Thompson, 2014). The realization of the interpersonal meaning is through the use of Mood structure comprising the Mood, Finite and Residue (Eggins, 2004). The Mood part involves the Subject, realized by a nominal group, and the Finite as a part of a verbal group (Gerot \& Wignel, 1994; Eggins, 2004). The Finite is commonly written/spoken in the present tense (lexical verb) such as maintain, assemble, check, etc. It also appears in the verbs 'be' such as 'is' or 'are'. The other form of Finite is modal verbs to show probability and obligation. Concerning Residue, it is composed by Predicator in the form of nonfinite verb, Complement in the form of noun or nominal group, and Adjuncts in the form of adverbial group, and a prepositional phrase (Halliday, 1994; Gerot \& Wignell, 1994; Eggins, 2004).

\section{Method}

This study is intended to investigate how interpersonal meaning is realized in students' explanation texts based on SFL perspectives. By using a descriptive qualitative approach, the data were collected through the documentation of students' texts taken from six writings represented the high, mid, and low achievers. Following Halliday and Matthiessen' work on the grammar of interaction from a semantic perspective (2004), the texts were first analyzed in terms of mood system by identifying the Subject and Finite in the clauses. After that, the analysis was continued by identifying the mood types as the realization of the speech functions. Then, the clauses found in the students' explanation texts were categorized in terms of modality; modalization and modality. Finally, the results were interpreted to find out the realization of interpersonal meaning in students' explanation texts.

\section{Findings and discussion}

The realization of interpersonal meaning can be derived through analyzing Mood structure in students' explanation texts in terms of mood types and modality in the clauses and sentences. Based on the findings, there were 60 sentences with 96 clauses. In terms of mood types, it was found that almost all the sentences were in the form of declarative. The elaboration is presented in the following table. 
Table 3.

The Mood Types in Students' Explanation Texts

\begin{tabular}{ccc}
\hline Mood Types & Total & Percentage \\
\hline Declarative & 58 & $97 \%$ \\
\hline Interrogative & - & - \\
\hline Imperative & 2 & $3 \%$ \\
\hline
\end{tabular}

Table 3 shows that almost all students employed a declarative form in their texts $97 \%$ that represents 58 sentences), and 3\% that represents six sentences were written in imperative, but none of the students used interrogative mood types. The interpersonal meaning can be seen from the writer's choice of the declarative mood. It indicates that the students are aware that the readers are the recipient of information (Eggins, 2004). The dominant use of declarative sentences in students' explanation texts is considered relevant with the feature of explanation text which is to give information. The examples of the mood types realized in students' explanation texts can be found in the following tables.

Table 4. The Example of Mood types realized in the student's text

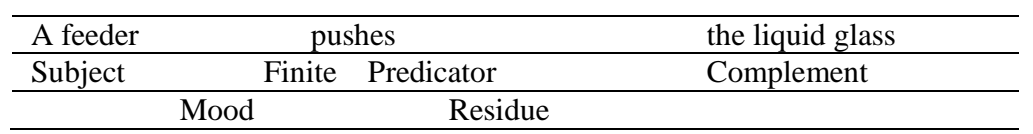

Table 4 shows the realization of mood types in the student's text. It was found that the Mood elements consist of Subject and Finite. Meanwhile, the Residue comprises Predicator and Complement. The Subject is realized in the form of a nominal group 'a feeder', and the Finite is the lexical verb fused with the predicator 'pushes' to show the present time.

Other examples of mood types in student's text are illustrated in the following tables.

Table 5. The Example of Mood types in terms of Finite

\begin{tabular}{ccc}
\hline The machine & will & process the workpiece \\
\hline Subject & Modal Finite & Predicator Complement \\
\hline Mood & Residue \\
\hline
\end{tabular}

Table 6. The Example of Mood types in terms of Finite

\begin{tabular}{|c|c|c|c|}
\hline Vice & is & made of & casting steel \\
\hline Subject & Finite & Predicator & Complement \\
\hline & od & Resid & \\
\hline
\end{tabular}

As it can be seen in Table 5, the clause consists of Subject and Finite as the Mood elements and Predicator and Complement as the Residue. The Subject is realized in the form of a nominal group 'the machine', and the Finite is realized by modal verb 'will'. Meanwhile, the Residue is realized by Predicator 'process', and Complement 'the workpiece'.

While table 6 describes the realization of mood types consisting of a Subject and Finite as Mood element and Complement as Residue. In this case, the Subject is realized by a proper noun 'Vice' and the Finite 'is' combined with predicator 'made' which precedes the Complement in the form of the nominal group 'casting steel' as the Residue.

The three clauses above show the elements of Mood system of Subject and Finite in the form of nominal groups and a noun, while the Residue is composed by complement and predicator. The Subjects 'a feeder', 'the machine', and 'vice' precede the Finite 'pushes', 'will', and 'is'. This order of Subject and Finite characterizes the speech function of a statement which is realized in a declarative form (Halliday, 1994; Gerrot \& Wignel, 1994; Butt, 2002; Eggins, 2004). The use of declarative in students' texts is relevant with the purpose of explanation texts which is to give information. In this case, the students tend to inform the reader about the process of how something is done and show their positions as presenters of information are having an equal level with the readers (Ivanic, 1998; Ivanic \& Camps, 2001). This indicates that the students were able to employ the social function of the explanation text which is to communicate how something happens, 
elaborating steps or any other procedures how the process is done (Gerot \& Wignell, 1994; Derewianka, 2004).

In terms of the realization of mood types in imperative sentences, the results can be seen in the following tables.

Table 7. The Example of Imperative Mood

\begin{tabular}{ll}
\hline Turn on & the machine \\
\hline Predicator & Complement \\
\hline & Residue
\end{tabular}

Table 8.

The Example of Imperative Mood negative polarity

\begin{tabular}{lcl}
\hline Don't & forget to turn off & the machine \\
\hline Finite: negative polarity & Predicator & Complement \\
\hline & Residue &
\end{tabular}

Both table 7 and 8 indicate that the clauses do not have explicit Subjects with a different structure. Table 7 shows that the clause only consisting of Predicator 'turn on' and Complement 'the machine'. While table 8 describes the Finite realized in negative polarity 'don't' combined with predicator 'forget to turn off' that precedes the Complement 'the machine'.

Concerning the modality, the students use several types of Modal Finite in the clauses. The Modal Finite 'can', 'may', 'will', 'could', and 'must' in an explanation text are applied to express the students' opinion towards a specific utterance in the text whether it is to indicate the probability, usuality, or obligation. The types of modality in students' explanation texts are presented in table 9.

Table 9.

The Modality in Students' Explanation Texts (adapted from Halliday, 1994)

\begin{tabular}{cccc}
\hline Type of Modality & Modality & $\begin{array}{c}\text { Degree of } \\
\text { Modality }\end{array}$ & Frequency \\
\hline Probability & will & middle & 7 \\
& can & low & 1 \\
& may & low & 1 \\
\hline Usuality & frequently & middle & 1 \\
\hline Obligation & must & high & 2 \\
& could & low & 1 \\
\hline Inclination & - & - & - \\
\hline Total & & & 13 \\
\hline
\end{tabular}

Table 9 shows the types of modality realized in students' explanation texts. Based on the findings, there are only small numbers of modality employed in the texts. It indicates that the students attempted to provide factual information for the readers which is relevant with the purpose of an explanation text which is to inform readers about why the phenomena happen or how something is done (Gerot \& Wignell, 1994; Derewianka, 2004).

The different degrees of modality demonstrates the different kinds of interpersonal relationship between the writer and the reader. Modality significantly contributes to set up the interpersonal meaning of clauses. It reveals to what degree the proposition or proposal is. Essentially, modality is concerned with the speaker/writer's opinion or judgment of the probabilities or the obligations related to what he says (Butt, 2002; Eggins, 2004; Halliday \& Matthiessen, 2004). The examples of the type of modality in students' explanation texts will be elaborated below.

'it can be ascertained that it's cut off because of overload (Text \#1).

The use of modality 'can' indicates the probability of an issue. The student tends to express that this step of a process needs to be based on the standard operating procedure. Modality signalling 
probability 'can' used in the text is to show a relatively certain and knowledgeable writer (Ivanic, 1998).

'The CNC machine could be started.....' (text \#2)

Modal verb 'could' in the clause above signals the low level of modality. It indicates the softer way of showing obligation instead of using a 'must' (Butt, 2002). With regard to the use of this type of modality, the student attempts to lessen his authority towards the readers, so it builds an equal level of the writer and the reader. Thus, the semantic meaning of 'could' found in the student's text shows the writer's opinion about the obligation of a specific action.

'It is at this stage that additional ingredients may be added to create various colours of glass.' (text \#3)

The use of the modal verb 'may' marks the low degree of modality. It also shows that the writer tries to weaken his authority towards the readers. It is mainly used to indicate the probability that something is done. This type of modality can be a sign that the writer gives an equal relationship with the reader.

'if the primary coil will be changed,' (text \#1)

'The machine will process the workpiece.' (text \#2)

'the number of coil rolls is counted to remember when it will be installed again.' (text \#1)

The clauses above show the use of modal verb 'will' informing the firm need and expectation. This type of modality indicates how powerful the speaker/writer's intention is. The modality 'will' belongs to a middle degree of modality indicating the message about something that is going to happen in the future.

'The design that has been made previously on solidwork must be copied to the USB.' (text \#2)

The obligation modality 'must' indicates a firm obligation. This is used to show the writer's judgment about the obligation on some particular issues. The use of such obligation modality helps to position the writer to specify what others should do (Ivanic, 1998; Ivanic \& camps, 2001; Martin and Rose, 2008).

Interestingly, one student uses the expression to show the orientation of modality in the text (Xuan and Huang, 2017). The expression 'It is recommended that.... (text\#1)' describes the student's attempt to explicitly state his objective that the action is needed to be done. She prefers to use passive voice with introductory 'It' instead of using modal verb 'should'. She tends to create equal relationships with the reader by not directly asking to do the action.

Another interesting finding is the use of modal adverb in the student' text. The clause 'The raw materials for making modern glass are silica sand, soda ash, limestone, and frequently magnesium oxide and aluminium oxide. (text \#3)' The student uses the modal adverb 'frequently' showing the objective orientation (Halliday and Matthiessen, 2004). He tends to show that he proposes the usual kind of material needed to form a particular object.

However, some students did not use any expression referring to modalization and modulation types in their texts (Texts \#4, \#5, and \#6). This suggests that the students prefer to present their texts as factual information instead of demanding information. This shows that the students have established equal relationships with their readers. Thus, the absence of modality in some of the students' texts suggests less persuasive power of the explanation texts which is relevant to the social purpose of the explanation text.

\section{Conclusion}

The study has revealed the analysis of interpersonal meaning in the students' explanation texts based on SFL perspectives. The findings demonstrate that students have applied mood types which are realized by the Subject and Finite as mood element and predicator and complement as Residue. The composition of Subject and Finite in the clauses describes the declarative mood which dominates the texts in realizing the speech function of the statement. It suggests that the students 
have attempted to provide the information to the readers correspond with the social purpose of the explanation text. It is also found that the students use a small number of modality in their texts. It indicates that the students try to present factual information by giving an equal relationship with the

reader. These imply how the students make efforts to position themselves in texts and how they build relationships with the readers. It can be concluded that students have been able to create a successful explanation text by employing appropriate speech function of the statement as to give information about how something is done.

\section{Acknowledgment}

The authors acknowledge Politeknik Manufaktur Bandung for providing financial support through the Polman Research Project.

\section{References}

Amalia, M., Subandowo, D., Faliyanti, E., Thresia, F. (2018). An Analysis of Domain Mood and Modality of Interpersonal Meaning in Susilo Bambang Yudhoyono (SBY)'s Speech. English Language Teaching Educational Journal, 1(1), 22-28.

Arifin., A. (2018). How non-native writers realize their interpersonal meaning? Lingua Cultura, 12(2), 155-161. https://doi.org/10.21512/lc.v12i2.3729

Ayoola, M. O. (2013). An interpersonal metafunction analysis of some selected political advertisements in some Nigerian newspapers. International Journal of Humanities and Social Science, 3(8), 165-178.

Butt, D., Fahey, R., Feez, S., Spinks, S., and Yallop, C. (2000). Using Functional Grammar An Explorer's Guide. New South Wales: Southdown Press Pty Ltd.

Cullen, B. \& Pudwill, L. (2002). "Presentations in The Technical English Classroom", Bulletin of Nagoya Institute of Technology, 53, pp 57-64.

Derewianka, B. (2004). Exploring How Texts Work. Rozelle: Primary English Teacher Association.

Eggins, S. (2004). An Introduction to Systemic Functional Linguistics. London: Pinter.

Feng, H., \& Liu, Y. (2010). Analysis of interpersonal meaning in public speeches - A case study of Obama's speech. Journal of Language Teaching and Research, 1(6), 825-829. https://doi.org/10.4304/jltr.1.6.825-829.

Gerot, L. \& Wignel, P. (1994). Making Sense of Functional Grammar. Cammeray: Antipodean Educational Enterprises.

Halliday, M.A.K. (1994). An Introduction to Functional Grammar. 2nd eds. London: Arnold.

Halliday, M. and Matthiessen, C. (2004). An Introduction to Functional Grammar. 3rd ed. London: Arnold.

Ivanic, R. (1998). Writing and Identity: The Discoursal Construction of identity in Academic Writing. Amsterdam: John Benjamins.

Ivanic, R and Camps, D. (2001). I am How I Sound: Voice as Self-Representation in L2 Writing. Journal of Second Language Writing. 10: 3-33.

Martin, J. and Rose, D. (2008). Genre Relations: Mapping Culture. London. Equinox Publishing Ltd. 
Sunardi, S., Tarjana, M. S., Poedjosoedarmo, S., \& Santosa, R. (2018). Interpersonal Realizations of Pedagogic Discourse in Indonesian EFL Classrooms. International Journal of Language Teaching and Education, 2 (3), 205-215. https://doi.org/10.22437/ijolte.v2i3.5678.

Thompson, G. (2014). Introducing Functional Grammar Third Edition. New York: Routledge.

Xuan, W.H. \& Huang, X.E. (2017). Understanding Interpersonal Meaning-Making in Chinese High School Students' ESL Writing: A Systemic Functional Perspective. Asia-Pacific Education Researcher. V. 26, no. 5, p. 227-238. DOI:10.1007/s40299-017-0343-4 http://hdl.handle.net/10397/75815

Yu, H. (2017). Interpersonal Meaning of Mood and Modality in English Public Service Advertising Texts. Proceeding of 7th International Conference on Education, Management, Information and Mechanical Engineering (EMIM 2017). Advances in Computer Science Research (ACSR), volume 76.

Yuliana, D., \& Imperiani, E. D. A. (2017). The Realization of Interpersonal Meaning in Course Newsletters: A Systemic Functional Linguistic Perspective. Indonesia Journal of Applied Linguistics, 7(1), 181-188. 